\title{
Activation of Former Industrial Areas: Creative and Civil Sector as Main Actors in Overcoming the Institutional Limitations in Serbia
}

\author{
Jasna Cizler \\ e-mail: cizlerj@gmail.com
}

\begin{abstract}
The subject of the research is the reuse of former industrial areas through innovative and bottom-up initiatives. These approaches have already been applied in other countries and are gradually emerging in Serbia, while facing several limitations. The first hypothesis is that the institutional framework and the existing policy for activation of these locations in Serbia are inadequate. The second hypothesis is that initiatives of the civil and creative sector can improve the results of the activation of former industrial buildings. The task was to investigate the practice of the activation in Serbia, to examine the limitations of this process and to indicate the possibilities for its improvement. Research methodology is qualitative and it involved interviews with relevant actors. The research focused on two case studies from Serbia: 1. Former brick factory complex - Trudbenik in Belgrade, and 2. Former industrial complex Kineska četvrt in Novi Sad. The research has shown that limitations in the institutional framework for the activation of former industrial buildings in Serbia could be overcome through a greater inclusion of non-institutional initiatives. The research resulted with an identification of guidelines aiming to introduce these innovations in urban development process.
\end{abstract}

Key words: industrial heritage, urban planning, institutions, non-institutional actors. 


\section{Introduction}

A large number of abandoned industrial heritage buildings in Serbia indicates that there is a need to change the approach to their management. The traditional instruments in urban planning and heritage protection are increasingly powerless in dealing with new challenges worldwide. In such context, a significant role is played by initiatives undertaken by non-institutional actors, such as the civil and creative sector. This paper explores how the existing institutional system in Serbia relates to such initiatives. The aim was to formulate guidelines for improving the process of activation of abandoned industrial buildings. The focus is on abandoned industrial areas that have a particular social, architectural and historical value, and are therefore recognized as an industrial heritage.

The first hypothesis is that the existing institutional framework of urban planning and heritage protection is inflexible and does not allow the application of innovative approaches necessary for the successful activation of abandoned industrial buildings in Serbia. There is a need for a greater flexibility and leaving room for unexpected changes, temporary use and greater involvement of non-institutional initiatives. The second hypothesis is that creative and civil sectors in Serbia have the capacity (creative and social capital) and the need to use industrial heritage buildings, and that they provide innovations that could contribute to changing the traditional models in the institutional framework and improving the treatment of abandoned industrial areas.

\section{Theoretical and Conceptual Framework of the Research}

The process of activation of industrial heritage buildings has already been a subject of numerous research (see for example: Stojanović, Janjušević, 2018; Cizler, 2012). Former industrial buildings and their reuse, are often associated with the identity of communities and entire cities, while culture and architectural heritage are increasingly recognised as an economic asset. At the same time, the instrumentalisation of culture and heritage in development policies has also been a subject of criticism. Large urban regeneration projects fail to succeed in producing non-commercial spaces, while the improvements of the places by creative sector results with gentrification $^{1}$, which is contrary to the initial intentions ${ }^{2}$. In such conditions, a reconsideration of the approaches to the activation of former industrial buildings is needed.

$\mathbf{1}$ The concept of gentrification indicates a process of physical, economic, social and cultural transformation of an area, resulting in an extension of the property system of the private ownership, resettlement and possibly marginalisation of former residents, by introducing individuals who share the same lifestyle and consumer preferences. Its negative effects are mostly felt by the less well-off and displaced households and small business (Tallon, 2010). 'Although gentrification is linked with urbanity of cities and diversity that makes creative cities attractive, it is also necessary to point out negative social aspects of the phenomenon - homogenization of neighbourhood, commercialization, privatization and fragmentation of urban space' (Backović, 2015).

2 E.g. urban regeneration of former industrial areas in Leeds, UK (Cizler, 2012). 
The role and importance of the initiatives of civil and creative sector in activating industrial buildings is related to contemporary social movements, based on the concept of the right to the city - the city as a product of all residents, who have the right to use, change and reinvent it $^{3}$ (Lefebvre, 1996; Harvey, 2009; Harvey, 2013). At the same time, cultural (industrial) heritage is recognized as a public good, a value to which all humans are entitled without paying and exclusion. Civil society and organised communities have a significant role in achieving this right.

Organised groups are capable of continuous responses and are therefore important for the protection of public interest and organising a dialogue with the authorities responsible for planning (Hirt and Stanilov, 2009). Civil society organisations enable citizens to articulate, defend and advocate their interests and are especially important for societies with weak institutions and limited resources, where creating partnerships can contribute to faster and more successful completion of the transition towards democracy (Golubović and Anđelković, 2008). In the countries where public institutions are underdeveloped or damaged, civil society and non-governmental organisations implement programs that, under different circumstances, would have been implemented by the government (Ćopić and Dragičević Šešic, 2014).

The solution for unused spaces is increasingly found in temporary use and the initiatives of the local community, young creative people and volunteers (Oswalt, Overmeyer and Misselwitz, 2013). The change in public attitudes towards the industrial heritage and the recognition of its values are associated with the protests and initiatives which originated from the volunteers and enthusiasts beyond the formal institutions. Creative and civil sector are a source of innovations, through discovering new ways of using old sites, but also through pointing to the problems, spreading information and drawing attention to the site and its potentials, protecting the heritage from demolition and dominantly commercial interests through the creation of alternative plans and solidarity with the marginalized groups.

In analysing the limitations in the present institutional framework in Serbia, neo-institutional theory has been applied. Neo-institutionalism is interested in 'bottom-up' institutional influences, and in how institutions are changing and evolving through the actions of different actors (Lowndes, 2009). The term 'institution' represents a set of formal and informal rules and procedures. The focus on the dynamic concept of institutions and the process of their adaptation is relevant for studying the institutions in the period of transition, as well as for studying their flexibility and the way they change under the influence of actors. According to Pavlović (2006), important questions in Serbia are: how institutional choices made in the previous times influence the creation of public policy today, and what are the possibilities for non-political institutions, especially institutions of the civil society, to influence the capacity and the quality of political institutions.

3 'The freedom to make and remake ourselves and our cities is, I want to argue, one of the most precious yet most neglected of our human rights' (Harvey, 2013). 
Transformations happening in post-socialist countries are shaped by historical legacy and in order to understand the actual institutional framework in Serbia, it is necessary to consider the problems related to the transition from the socialist to the present system. The transition process requires changes in managing the urban development and the improvements of regulatory framework, so that they are in harmony with the open market requirements. There is a need to change the traditional paradigms and instruments in urban planning, such as the comprehensive plans based on analysis and two-dimensional plans whose main function is to determine the land use and to avoid conflicts (Lazarević-Bajec, Maruna, 2009). This implies a greater flexibility and participation of non-institutional actors in the planning process. Most of the post-socialist countries have made significant steps towards democratisation during the process of transition, such as the introduction of new laws that require public participation in planning. Private stakeholders are gaining some authority and public-private partnerships are being formed, while the state keeps the regulatory and coordinative role. In practice, however, many obstacles remain (Hirt and Stanilov, 2009).

\section{Research Methodology}

The main research method is a comparative case study of the policy and practice related to the activation of abandoned industrial buildings in Serbia and in four EU countries $^{4}$ (UK, Czech Republic, Germany and Austria) ${ }^{5}$. The first hypothesis has been verified through analysing the current planning framework in Serbia and by comparing it with the one in developed countries, as well as through case studies aimed at confirming that the institutional framework in Serbia is inflexible and does not allow the use of innovative approaches. The second hypothesis has been verified through case studies from Serbia, which show that non-institutional actors have the potential to activate abandoned buildings and that they use innovations that lead to the overcoming of the existing limitations of the system.

Qualitative interviews represented an important component of the research process and they focused on how relevant actors (respondents) understand their own circumstances related to the use and purpose of the place, heritage protection, communication with other actors and institutions. A topic guide interview and informal conversations were used in the initial stages of the research as a method of examining the situation during the process of formulating the research topic, while

\footnotetext{
4 The complete description and analysis of the selected case studies is available in the author's PhD Thesis: Cizler, J. (2016). Activation of former industrial areas in cities: Institutional limitations in Serbia. Belgrade: Faculty of Architecture, University of Belgrade.

5 Selected cases from developed countries are: former cigarette factory Tabakfabrik in Linz, Austria, Zeche Zollverein and Emscher Park in Germany, Custard Factory in Birmingham, UK and Vankovka in Brno, Czech Republic. The criteria for choosing the activation cases were: application of innovative approaches; being recognised as relevant and/or good examples by the experts; recognition of industrial buildings on the site as cultural heritage and the possibility to do the research on the site (or alternatively - availability of data online).
} 
17 structured open-ended questions interviews were conducted with relevant actors in Serbia in 2015. The respondents were chosen by using the snowball sampling method - initial primary data sources nominated another potential primary data sources to be used in the research.

Two groups of questions were created for the needs of the interviewing - one for experts from the public institutions (local government, planning and heritage protection) and one for the actors who use former industrial areas today (representatives of the creative sector in two selected case studies: Trudbenik in Belgrade and Kineska četvrt in Novi $\mathrm{Sad}^{6}$ ). The questions were formulated to examine the institutional framework for the activation of abandoned industrial buildings, the use of innovative approaches, the cooperation between actors, the role of non-institutional actors, as well as their impact on the formal system ${ }^{7}$. The analysis of the gathered data indicates the ways in which these actors use former industrial buildings today, the innovations they apply and the response of the formal institutional system to it.

The interview respondents for the case study of Trudbenik were the following: 1) Marija Milovanović, architect and planner, Urban Planning Institute of Belgrade; 2) Žaklina Gligorijević, architect and planner in Urban Planning Institute of Belgrade; 3) Saša Mihajlov, art historian, Institute for the Protection of Cultural Monuments of Belgrade; 4) Rifat Kulenović, industrial archeologist, Museum of Science and Technology / The Museum of Yugoslavia; 5) Aleksandar Jocić, lawyer, Deputy chief of the Municipality of Palilula; 6) Jelena Varajić, economist, executive director of the IGM Trudbenik a.d.; 7) Viktor Kiš, artist and founder of Club Ciglana; 8) Dušan Kuzmanov, director of the Festival 9.

The interview respondents for the case study of Kineska četvrt were the following: 1) Katarina Maksimov, architect, Institute for the Protection of Cultural Monuments of Novi Sad; 2) Employee of the JP Poslovni prostor (who chose to be anonymous); 3) Former employee of the City Administration in the field of urbanism (who chose to be anonymous); 4) Ivana Korać, architect, founder of the Pro.polis and collaborator of the Institut for the Protection of Cultural Monuments in a period 2009-2012; 5) Nemanja Milenković, EXIT foundation, at that time director of the committee for the candidacy of Novi Sad for the European Capital of Culture 2021 and leader of the project European Youth Capital of Europe 2019; 6) Miloš Ignjatović, director of the festival Cinema City; 7) Siniša Žarin, owner of the company Manual and Museum of Forgotten Arts; 8) Nikola Rajić and Marko Vučić, members of the Social center (Društveni centar); 9) Ivan Fece Firči, owner of the Firchie Think Thank Studio.

6 The criteria for choosing the cases in Serbia were: being a former industrial area which is curently in the process of activation; the presence of creative and civil sector members on the site, contributing to its reuse; and the recognition of industrial buildings on the site as cultural (industrial) heritage.

7 The complete list of interview questions is available in author's PhD Thesis (Cizler, 2016). 


\section{Activation of Former Industrial Areas in Serbia: Overview and Discussion of the Research Results}

\subsection{Analysis of the institutional limitations for the activation}

1a Public policy content and formulation, decision-making process. Urban planning system in Serbia lags behind the one in developed countries and, unlike in most other European post-socialist countries, land policy and property reforms have been implemented only partially (Nedović-Budić, Zeković and Vujošević, 2012). The current model faces the challenge of transitioning to the market-oriented and democratic system and encounters a number of limitations. The quality of the legislation varies and some of it is not fully applicable, while the very implementation of laws is often poor due to the weakness of formal institutions. The work of the government departments is characterised by a lack of coordination and by a strong influence of political parties (Vujošević, Zeković and Maričić, 2010).

The protection of cultural heritage has been insufficient and sporadic. Industrial heritage buildings have been recognised in the official public policy only in the last few years, and there is no systematic approach and cooperation in the identification, protection and activation of them. The efficiency of institutions in terms of protection and activation is further affected by unresolved ownership issues, lack of information about buildings and complicated bureaucracy.

Interviews with experts from the institutions confirmed that the protection procedures are long, that there is a lack of financial resources and that the number of experts working on these issues in formal institutions is insufficient ( $\mathrm{S}$. Mihailov, personal interview, Oct 30, 2015; K. Maksimov, personal interview, Dec 3, 2015). Another problem in protection and activation is a lack of understanding about the importance of heritage in general, as well as inappropriate new uses that occur as a consequence:

'There is a lack of understanding between decision-makers, building owners and users... Sometimes you have to make an effort and spend a lot of energy in order to make those who want to activate the building understand that it is extremely valuable and that it has to be protected' (S. Mihajlov, personal interview, Oct 30, 2015)

2a Cooperation between actors and institutions. There is a lack of cooperation and coordination among the institutions in charge of the heritage protection, as well as the lack of cooperation of institutions with non-institutional actors. Due to a lack of financial resources and experts working on this issue, the control over the implementation of procedures is often missing (Stojanović and Vukanović, 2014; Vukanović, 2011). The public is included in planning only formally, at the end of the plan making process. Unlike in developed countries, where a large number of actors is involved in planning and the interest for this issue among the citizens is strong from the earliest stages of planning, citizens in Serbia are not interested in the 
decision-making process and public participation is poor. Low levels of cooperation, participation and initiative regarding the use of space in most of the cities, represent the limitation for the activation of industrial heritage buildings.

\section{3a Flexibility and openness of the formal planning and beritage protection} systems. Planning procedures had not been market-oriented until recently. The inherited planning and heritage protection model is based on a rational planning paradigm, focusing on physical planning and a hierarchy of plans - resulting with rigidity and a complicated adoption procedure, while temporary uses are not recognised and supported. The heritage protection policy in Serbia has been centralized since the 1990s and the state is the dominant actor in the protection. Changes that have emerged after 2000 involve the gradual inclusion of the private sector, but its involvement is still insufficient. There are no incentives to finance derelict buildings and strict rules set by the heritage protection institutions are often unachievable and can be an obstacle for the activation. The significance and economic potential of the activation of abandoned industrial areas are still insufficiently understood. For all these reasons, the practice of activation in Serbia is rare (Cizler, 2016).

\subsection{Innovative approaches to the activation of former industrial buildings in Serbia}

A number of civil and creative sector initiatives, dealing with heritage and abandoned spaces in the country, apply innovative mechanisms in their approach. Through networking with actors from the public, private and civil sectors in their projects, these actors contribute to the management of unused buildings, either through using the sites for different activities or by spreading awareness about their significance. Actors from creative and civil sector play an important role in several districts in Belgrade: Savamala (European Center for Culture and Debate - Grad, Magacin in Kraljevića Marka), Cetinjska Street (former brewery complex), BIM Slavija and Port of Belgrade (Luka Beograd). Although to a smaller extent, similar examples are emerging in other cities, too. The review of the most important activities related to the activation of unused spaces and heritage buildings, done for the purpose of this research, shows that a significant share of these activities was realised by non-institutional actors (e.g. the activities of Ministarstvo Prostora, Kulturklammer, Kulturni Front, Evropa Nostra, Građanske inicijative, Palgo Center, Ko gradi grad, Grupa za kreativnu ekonomiju, Suburbium...) (Cizler, 2016).

\subsubsection{Case study: Complex of the Trudbenik factory in Belgrade}

Pottery production started in the area today known as Palilula at the beginning of $19^{\text {th }}$ century. Several brick factories were built around 1900 in the area around the street Slanački put (Ciglana Polet, Ciglana Rekord, Ciglana Kozara). These brick factories are in poor condition today and do not have the status of cultural heritage, but are registered by the Museum of Science and Technology (Kulenović, 2010:31- 
33). The company for the production of bricks and tiles 'Trudbenik' was founded in 1946 and this is now a joint-stock company IGM 'Trudbenik'. Since 2012, within the framework of the reorganisation plan, all production plants in the Trudbenik complex near Slanački put have been converted into warehouse facilities, offices, workshops, or are not in use. The place is used by some 200 tenants, including members of the creative sector.

Fig. 1

Map showing the Trudbenik complex and the surrounding in 2018

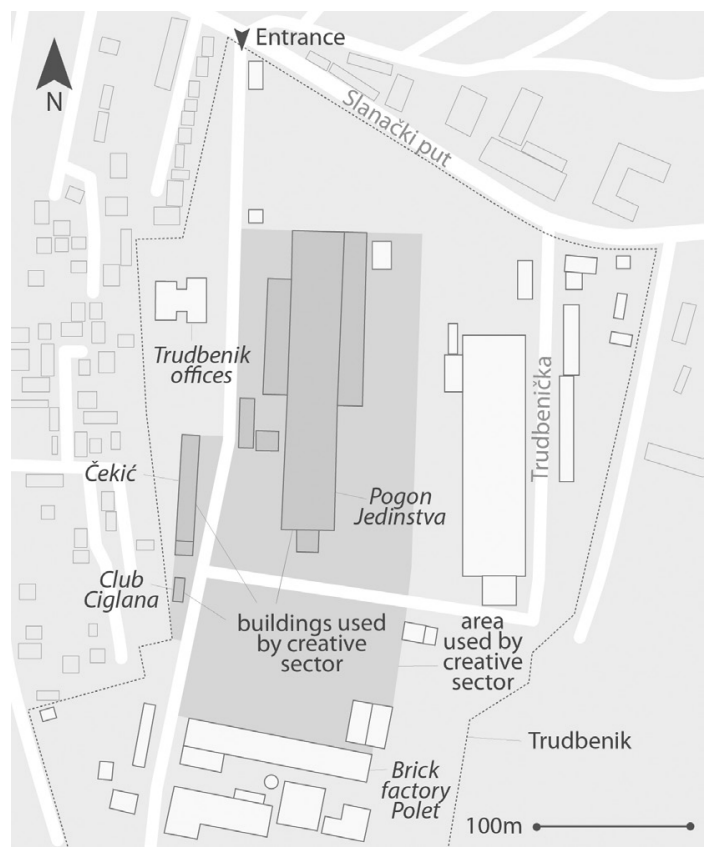

Source: author

$1 b$ Organisation and management of the activation process. All interview respondents from public institutions (Urban Planning Institute of Belgrade, Institute for the Protection of Cultural Monuments of the City of Belgrade, Museum of Science and Technology, City Administration of the Municipality of Palilula) have a positive attitude towards the involvement of actors from the creative and civil sector in the activation of industrial heritage buildings. Gligorijević, planner in the Urban Planning Institute, stated that initiatives for the activation of abandoned buildings are taken into account when developing strategies and creating plans. However, support is often only nominal, especially in situations when the sites can be commercialised and are not protected as cultural heritage (̌̌. Gligorijević, personal interview, Oct 28, 2015).

The process of creating the club 'Ciglana - Klub ljubitelja teške industrije' in this complex, started spontaneously in 2012 and expanded from one to several buildings. According to Kiš, artist and its founder, temporary use in the complex con- 
tributes to the maintenance of the site and the preservation of the infrastructure $(\mathrm{V}$. Kiš, personal interview, Oct 27, 2015). The specific location and its atmosphere play a significant role for its users, who recycle the material they find on the site when redesigning the space:

'This ambient has helped me a lot. People see these abandoned spaces as something exotic. But this is not just exotic, it is really an ideal place for noisy activities and various other activities that involve a totaly free behaviour. You can practically do what you want' (Kiš, personal interview, Oct 27, 2015).

After this initiative, several spaces in the complex were turned into galleries, workshops and places for events. However, the fact that buildings are not protected as cultural monuments means that they will probably be demolished in the future.

Festival 9 has taken place in the Trudbenik complex since 2015. This event helped to temporary activate several more areas and buildings. All interview respondents confirmed that a very good cooperation was achieved among the actors during the festival. The cooperation began in the form of informal conversations with the local administration. The assistance provided by the municipality was not material, but rather moral and logistic, and consisted of support and referral to other relevant actors and institutions through formal, institutional, as well as personal contacts (e.g. using the old public transport company's bus for artistic interventions) (A. Jocić, personal interview, Nov 4, 2015; D. Kuzmanov, personal interview, Oct 27, 2015; V. Kiš, personal interview, Oct 27, 2015). The festival was supported by the owners and the administration of Trudbenik. They understood that such events contribute to increasing the attractiveness of the location, and have given one of the buildings for a temporary use without compensation (D. Kuzmanov, personal interview, Oct 27, 2015).

Fig. 2 and 3

Brick factory Polet and the area used as an open air cinema during the Festival 9
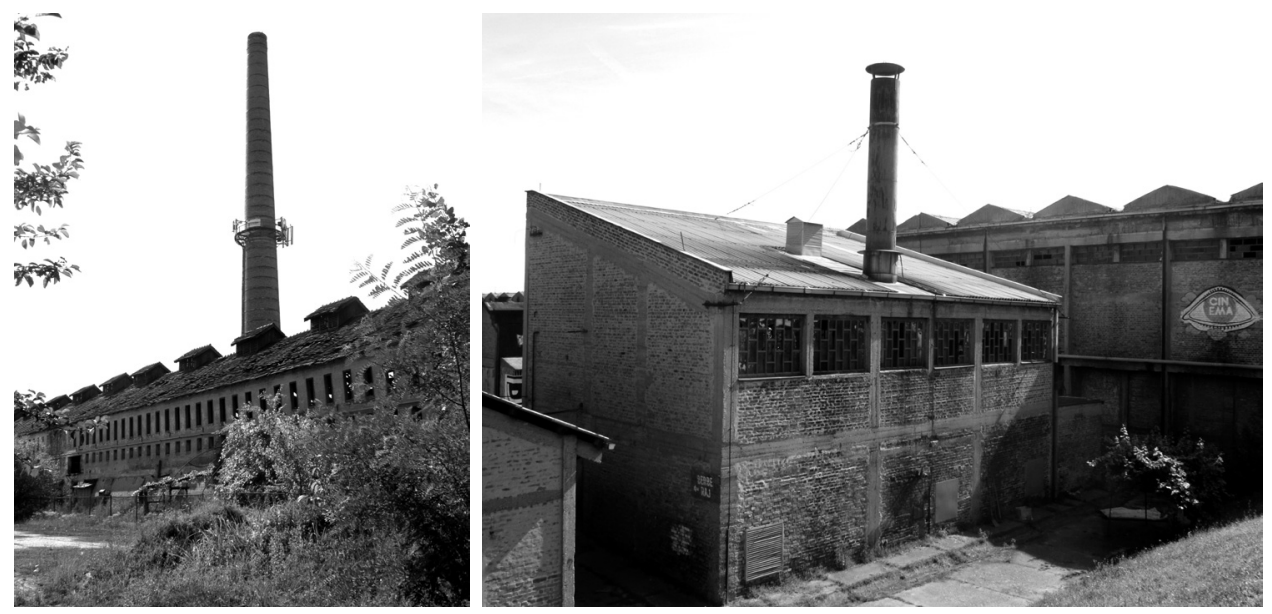

Source: author, 2015 
$2 b$ Problems, conflicts and their resolution. The management team of Trudbenik saw the long process of waiting for new laws and plans as one of the main problems related to the use of the space (I. Varajić, personal interview, Nov 5, 2015). The lack of plans for this area limited further planning and development of the site, and it prevented owners from investing in the existing buildings. In the General Urban Plan (Plan generalne regulacije) adopted in 2016 for part of the complex, none of the industrial buildings is recognized as significant (Official Gazette of Belgrade, No. 20/16). The Museum of Science and Technology and the Institute for the Protection of Cultural Monuments have good cooperation and they have registered old brick factories in this area, but detailed studies that would assess their value have not been conducted yet (S. Mihajlov, personal interview, Oct 30, 2015; R. Kulenović, personal interview, Oct 21, 2015). Although there is awareness of the value of industrial heritage at the site, the management team of Trudbenik does not see the cost-effectiveness in the activation and reuse of the former brick factory (Ciglana Polet), which is used as a warehouse (I. Varajić, personal interview, Nov 5, 2015).

The problems and conflicts between actors are solved through dialogue and agreement during the process (for example: regarding the safety, noise control, large number of visitors and increased traffic during the events). Opening of the pools in one of the former production buildings for the public (Pogon Jedinstva) has at first caused fear related to the safety of the site. However, it was later described as 'The best thing at the festival and something that Belgrade has not seen before (Varajić, 2015).

Temporary use is characterized by uncertainty. Users invest in cleaning and maintenance of the unused areas, thus making them not only usable, but also rentable. Nevertheless, all users are renting the space in this complex only until the new purposes are established, after which they will have to move out.

Although the cooperation between the actors was evaluated as good by all respondents, neither the Institute for the Protection of Cultural Monuments of the City of Belgrade, nor the Museum of Science and Technology had any cooperation with the owners and actors in the Trudbenik complex. This is because the buildings are not protected by law as a cultural monument (S. Mihajlov, personal interview, Oct 30, 2015; R. Kulenović, personal interview, Oct 21, 2015). 
Fig. 4 and 5

Art in the former brick factory buildings
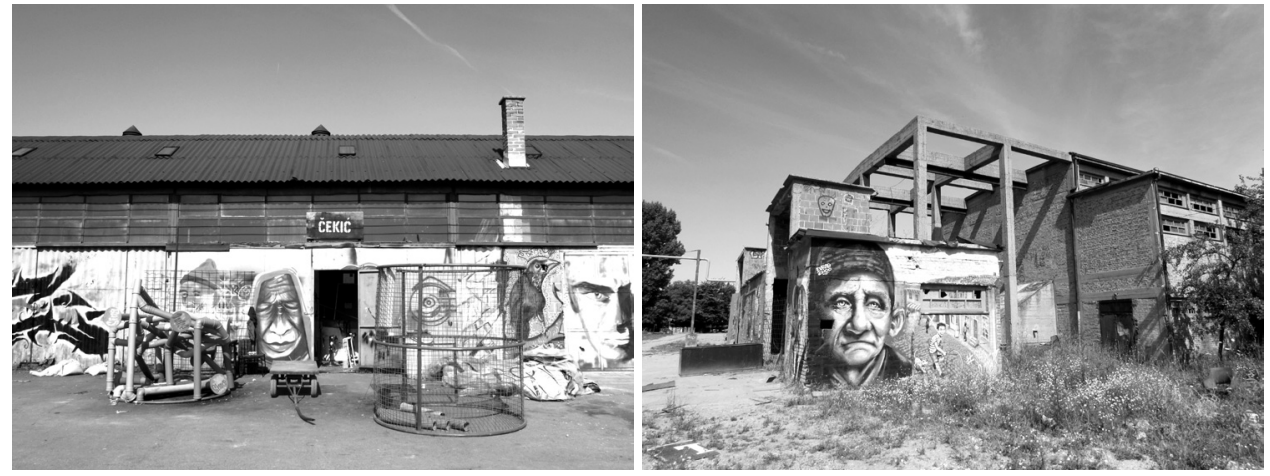

Source: author, 2015

\section{Innovations and contribution to changing the formal institutional frame-}

work. The informal aspect of the activation process is seen in the networking between actors through using the personal contacts they have. These processes require that actors who have power recognise the value and support these initiatives. Jocić, an interviewee from the Municipality of Palilula, stated that people often show resistance to unusual processes, mostly due to the fear of failure or violation of regulations. It is necessary to change this, so that the actors who manage the space have a wider picture and allow processes such as temporary uses, which is particularly important in situations when it is not possible to help through providing material resources $^{8}$ (A. Jocić, personal interview, Nov 4, 2015). Unlike the owners who, in the absence of a plan, restrain from intervening and investing in buildings, the representatives of the creative and civil sector accept temporary uses and invest in the space even when long-term uses and the future are uncertain. They do it either by direct interventions on the site or by initiating a process of cooperation that leads to the improvement of the place. The activities of the creative sector in this area are particularly important given that the residential areas around Trudbenik are of low quality and characterised by the lack of open spaces and social infrastructure.

\subsubsection{Case Study: Former factory Petar Drapšin (Kineska četvrt) in Novi Sad}

Kineska četvrt (Chinese quarter) is located in the former industrial complex 'Petar Drapšin', between the Danube River and the residential area Liman. It represents one of the largest industrial heritage areas in Novi Sad (2.65ha). It consisted of 27 buildings, built in the period 1920-1970, of which 20\% were ruined and are not used

8 'We help when we can. These are the contacts that cost nothing but good will and asking someone to send you a positive signal that they will do it. These are the pieces in the mosaic, which become a big thing when assembled' (A. Jocić, personal interview, Nov 4, 2015). 
(Official Gazette of the City of Novi Sad, No. 17/17; Dević, Komnenić, Mikić, 2015). Several of these buildings were recently demolished as a part of the regeneration of the area. The complex is owned and managed by the City of Novi Sad.

Fig. 6

Map showing Kineska četvrt and the surrounding in 2018

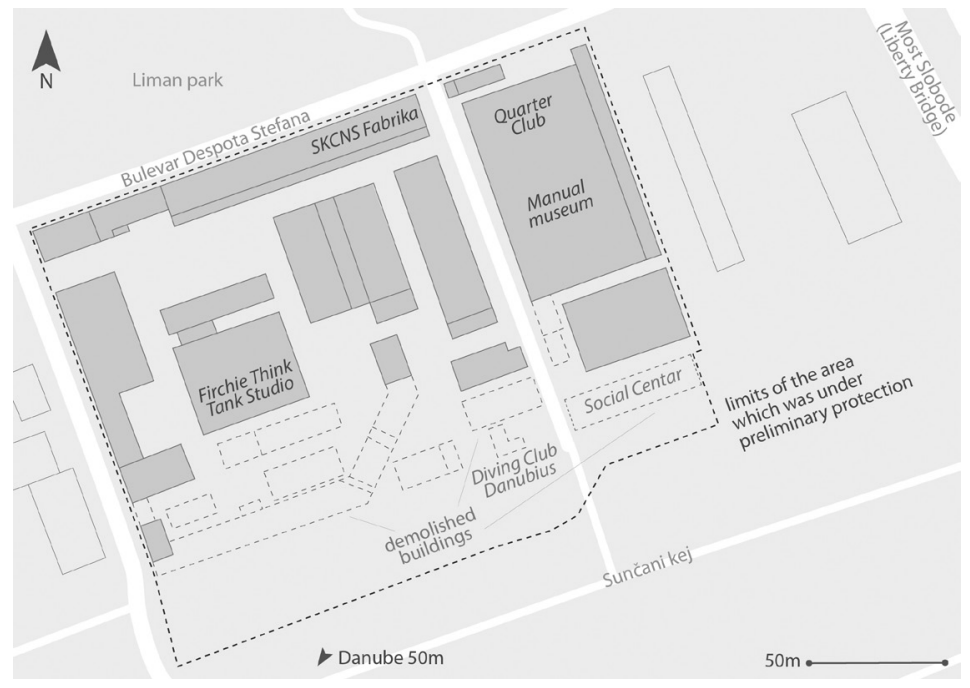

Source: author

1b Organisation and management of the activation process. The activation of unused buildings began after the relocation of the original industry to the north of the city - first for technical workshops and later for artists' studios, cafes, restaurants, clubs, Manual Museum, Students Cultural Center - SKCNS Fabrika, etc. In most cases, the reuse started as a gradual adaptation of the buildings, which were in a very poor condition, by the users themselves. In this way, the users contribute to the preservation of buildings when the institutions do not have the capacity to do it. Fece, owner of the Firchie Think Tank studio, confirmed that the users play a significant role in protecting the complex: 'If we were not there, this would have collapsed 10 years ago' (I. Fece, personal interview, Dec 3, 2015).

The issues of preservation and adaptation of the existing buildings started to occur in official documents only in 2010 and the investments in the complex were very rare. Since the major part of the complex is in public ownership, the public company JP Poslovni prostor was in charge for the realization of the projects, adaptation and maintenance of the facilities until $2017^{\circ}$. In the last few years, the activities of the City Administration have been related to the candidacy of Novi Sad for the European Youth Capital and the European Capital of Culture. Kineska četvrt is recognised as an important location for creative industries in both candidatures. As a result of the

9 This company became in 2017 part of the City Administration - Gradska uprava za imovinu i imovinsko-pravne poslove, Sektor poslovnog prostora). 
two candidatures, a more active cooperation has been established between public institutions JP Urbanizam and JP Poslovni prostor (employee of the JP Poslovni prostor, personal interview, Dec 9, 2015). The current public policy for this area is related to converting it into a 'cultural quarter', which implies excluding some of the present space uses, such as artisan's workshops and warehouses.

The complex of the former factory 'Petar Drapšin' was registered as a space under preliminary protection in the period 2013-2016, and is not under any legal protection at the moment. The process of protection started through the civic initiative of the organisation Pro.polis - Centar za jačanje kulturnog imuniteta grada, created to protect the complex from demolition (K. Maksimov, personal interview, Dec 3, 2015; Korać and Mirković, 2009). Maksimov, architect in the Institute for the Protection of Cultural Monuments of Novi Sad, confirmed that users do not contact the Institute regarding the interventions on facilities, and that the Institute itself rarely controls the changes, due to the fact that only one expert deals with industrial heritage and the priority is given to more important buildings. Minor changes on buildings, which do not endanger the complex significantly, were not seen as a threat and were tolerated.

$2 b$ Problems, conflicts and their resolution. One of the main problems in the past was the lack of interest and understanding of the importance and the potentials of the quarter by the city administration. M. Ignjatović, organiser of the Cinema City festival, stated that the problem was the lack of a strategy on the city level, and only in this way the infrastructural limitations on the site, which are out of reach for small organizations, could be solved (M. Ignjatović, personal interview, Nov 11, 2015). Even in the periods when the city was interested in the regeneration of the quarter, the capacity for implementation was lacking. The rigid legislation left no space for innovation. Numerous meetings, workshops and discussions did not lead to changes (former employee of the City Administration, personal interview, Dec 3, 2015). Although all space users in Kineska četvrt agree that mutual cooperation is excellent, there was no cooperation and exchange of information between different stakeholders and the institutions.

When it comes to the problems related to the location itself, they concern the poor condition of the buildings and the absence of basic infrastructure and installations (I. Fece, personal interview, Dec 3, 2015; I. Korać, personal interview, Nov 11, 2015; employee of the JP Poslovni prostor, personal interview, Dec 9, 2015). The question is if the interventions of the users on the buildings are adequate. Many of the adaptations were carried out without informing the relevant institutions, and the institutions themselves due to the limited capacities are not able to follow all the interventions (employee of the JP Poslovni prostor, personal interview, Dec 9, 2015). Informal conversations and interviews showed that the awareness among the users about the importance of cultural heritage in the complex is very low.

There was a lack of support for the non-profit activities on the location, and future uses were often determined on a commercial basis. Unlike the flexible approaches that exist abroad, which take into consideration the current users and their needs, the approach in Kineska četvrt prevented any long-term planning for the current 
users. They invested significant funds in its maintenance, even though their renting contracts could end as soon as the new functions are introduced. As a result of a greater number of actors interested in Kineska četvrt, the issue of gentrification is increasingly associated with it. The question is whether the space users will be able to afford the rent after its atractiveness and price rise, and regardless to the fact that they have previously contributed to it:

'I think that this is a small gold mine and it could be even more. It is a ray of light in the darkness. Creative industries are relevant, they are leaders in many things. The alternative culture exists, but it is suppressed and marginalized' (M. Ignjatović, personal interview, Nov 11, 2015).

Conflicts existed between the actors from Društveni centar (Social Center), who adapted a previously unused building, and the public company who managed it (JP Poslovni prostor), regarding the unregulated renting of the space. They led to lawsuits and the temporary closing of the center. Members of Društveni centar stated in the interview that there is no recognition of what this organization has done for the alternative scene on voluntary basis (N. Rajić and M. Vučić, personal interview, Dec 9, 2015). This case shows the lacking cooperation and understanding between the formal institutions and bottom-up initiatives, among which the latter turn the unused space into an active part of the city:

'This is a weird situation where we are being sued and evicted from the site, while at the same time there is advocation for cultural and youth capital. Places like this one do not exist in the city, they are not recognised' (N. Rajić and M. Vučić, personal interview, Dec 9, 2015).

Fig. 7 and 8

A building used by the Manual Museum and a 'stop gentrification' inscription on one of the facades in Kineska četvrt
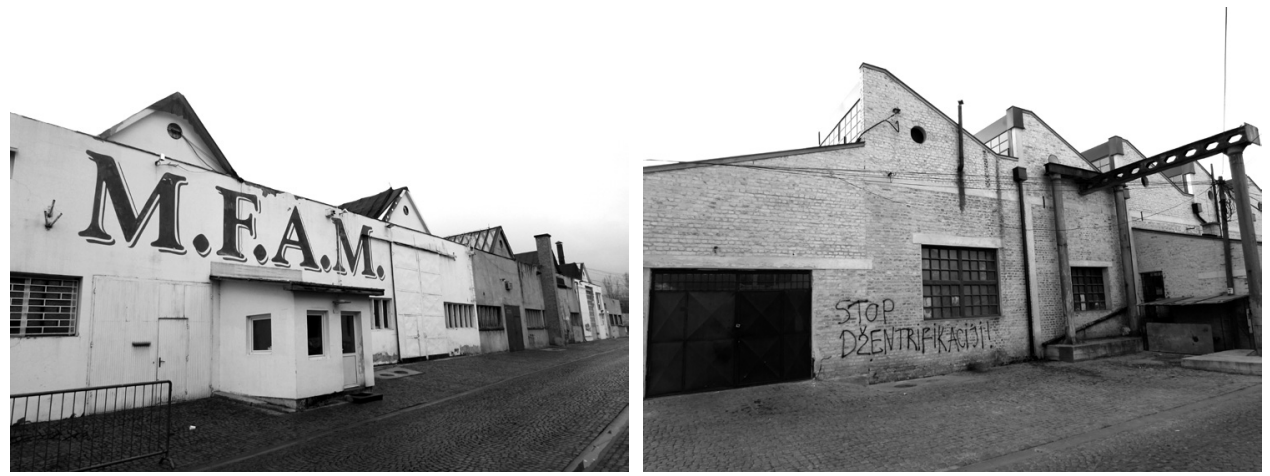

Source: author, 2015

3 Innovations and contribution to changing the formal institutional framework. Non-institutional actors and their activities related to the activation of space, contribute to the fact that more and more people want to preserve this complex. 
Under such conditions, the existence of formal legal protection might not be the prerequisite for the preservation. As Maksimov states, legal protection of the building as a cultural monument is only one of the ways to preserve it:

'Everything started informally. The industrial architecture has been, until recently, recognised only when people came and told us about them ... It seems to me that too many actors have entered that space, started to love it and that it has begun to live. I do not believe that when the legal aspect of the protection expires, somebody will just decide to tear down everything' (K. Maksimov, personal interview, Dec 3, 2015).

When speaking about the innovations of the creative and civil sector, it is important to mention the Pro.polis initiative. This initiative produced a draft strategic plan for the revitalization of the quarter, proposing the creation of 'new cultural centers on the platforms of industrial heritage' with the gradual revitalization which allows the new uses to be determined according to the real needs, thus avoiding big and insecure investments (Korać and Marković, 2009:3). During the creation of this document, the authors conducted interviews with city experts and drew their attention to the complex and its potentials. More importantly, the contact was established with the Institute for the Protection of Monuments, and the process of valorization of the complex as a cultural monument was initiated (I. Korać, personal interview, Nov 11, 2015; K. Maksimov, personal interview, Dec 3, 2015). Some of the concepts proposed in this draft in 2009 can be recognized in the public policy today: the gradual complex development and the involvement of creative industries in the program development.

Many of the initiatives and actors who use the spaces in Kineska četvrt have contributed to its protection and gradual activation. However, although they have great potential, the creative sector and bottom-up initiatives often fail to turn ideas into practice and to become recognized by the formal institutions. There is a lack of joint action and stronger initiative of these actors, as well as the lack of public administration's response (N. Milenković, personal interview, Nov 20, 2015). In such a situation, the candidacy for the European capital could be seen as a process that encouraged the engagement of the public administration, but also of the space users, who formed the Council of the quarter (Savet Kineske četvrti) in 2015. The goal was to advocate the common interests concerning the future of the site, as well as to provide mutual support in solving everyday problems (I. Fece, personal interview, Dec 3, 2015). The occasional events, such as festivals and activities of the users, contributed to the gradual resolution of problems on the site through the maintenance of the facilities and their surroundings.

Some flexibility starts to emerge in the formal policy and it represents an innovation in the system characterised by the limitations. In a document of the public company JP Urbanizam, which deals with brownfields, it is stated that efforts are made to make plans as flexible as possible in order to attract the investors (JP Urbanizam [JPU], 2015: 2). In the same document, the values of flexibility and reusing the land and the buildings are recognised as important and favorable as a long-term solution, in comparison to the construction on the greenfields (JPU, 2015:21). 
Fig. 9

The concert and exhibition space of the Student Cultural Centre - SKCNS Fabrika, located in the former factory in Kineska četvrt

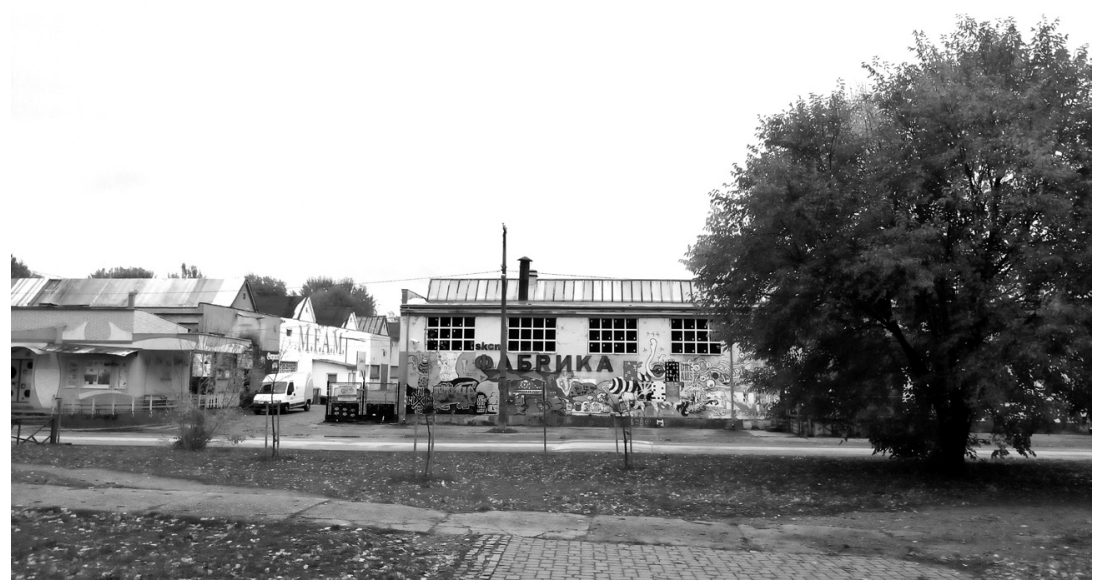

Source: author, 2017

\subsection{Recommendations for overcoming the institutional limitations and introducing innovations in the existing institutional framework in Serbia}

Analysis and comparison of the institutional frameworks and examples in different countries (Cizler, 2016) confirmed the first hypothesis - that the institutional framework in Serbia is inflexible and does not support the application of innovative approaches. Case studies from Serbia showed that non-institutional actors have the potential to activate abandoned industrial areas and that, during this process, they apply innovations which could lead to overcoming the limitations. This section of the article presents the recommendations for the institutional framework in Serbia.

1a Public policy content and formulation, decision-making process. Obstacles in the protection and activation of abandoned industrial heritage sites can be overcome through the adaptation of the existing institutional framework. It is necessary to develop institutions and mechanisms for vertical and horizontal coordination, such as the coordination and advisory bodies, forums for discussion, consensusbuilding institutions, and institutions for advocacy of various interests. In situations where the existing institutions are ineffective and are characterized by constraints, the establishment of new institutions can play a significant role.

In order to encourage the owners to protect and invest in these areas, measures (such as a special budget, subsidies, exemption from taxes, more flexible licensing, assistance in funding and removing the pollution) could be established. 
It is necessary to keep in mind the social aspect of urban regeneration and to protect the vulnerable groups during the urban regeneration through mechanisms such as those existing in other countries (e.g. the concept of 'Mild urban renewal' - Sanfte Stadterneuerung and Social plan - Sozialplan). In the process of transition to the market oriented economy and the introduction of private actors in the heritage management process, it is important that the legal framework ensures the accessibility of heritage to all citizens.

2a Cooperation between actors and institutions. In order to solve the question of abandoned industrial areas, it is necessary to establish links and partnerships between different institutions and sectors, and to institutionalise the mechanisms for the involvement of a larger number of actors, which would increase the level of public participation in Serbia. Civil society and the creative sector can play an important role by spreading awareness about the importance of this issue, while networks formed by these actors could have the role in critical observation of the work of the public and private sector. It is also necessary that the formal institutions recognize the role of these actors and involve them in the early stage of the planning process. Additionally, it is necessary to support these actors through various mechanisms, such as renting space under more favorable conditions, through subsidies, free consultations and technical support.

3a Flexibility and openness of the formal planning and the beritage protection systems. Temporary uses and other innovative concepts are being increasingly integrated into the official urban planning process as a strategic component and a supplement to traditional models (Oswalt, Overmeyer and Misselwitz, 2013; Senatsverwaltung für Stadtentwicklung Berlin, 2007). In developed countries, such as Germany, there are institutionalised mechanisms that facilitate temporary use, such as: agreements which allow temporary use without compensation, maintenance contracts and planning permission exemption.

One of the main factors contributing to the success of the activation, is previous existence of creative activities and temporary events on the site. Financial affordability of space, existence of a strong place identity, as well as flexibility are also important, and enable that these places can be adapted to the needs of different users.

The analyzed cases from EU countries fulfill most of these conditions, while the examples from Serbia show the lack of support from the formal institutions (Cizler, 2016). Regardless of the fact that there are currently no institutionalized mechanisms for it in Serbia, temporary use often occurs as a result of insufficient efficiency of institutions. Thus, partly as a result of the inability of the heritage protection system to follow all the changes, and partly as a recognition of the value of flexibility, formal institutions recognize the need for flexibility in the use of space. This could be seen in the relation of the Institute for the Protection of Cultural Monuments of the City of Novi Sad towards Kineska četvrt:

'We try not to introduce more restrictive measures and we meaningfully close eyes over the small-scale interventions, so that more people stay there and use the space' (K. Maksimov, personal interview, Dec 3, 2015). 
16 Organisation and management of the activation process. The recognition of the value of industrial heritage buildings and the initiatives for its activation by the owner is essential for the success of projects, regardless of whether they are public or private. In examples of good practice, when the place is publicly owned, formal institutions cooperate with actors on the site, but avoid excessive planning and regulation, in order to leave room for spontaneous development necessary for the creative sector, thus playing the role of mediator between the interests of the different actors.

$2 b$ Problems, conflicts and their resolution. Failure to recognize the value of the civil and creative sector in the process of activation of unused buildings leads to the lack of incentives for them, which exist in developed countries. In Serbia, where institutions often fail to provide the protection and reuse, the informal aspect of the activation process plays an important role and implies using personal contacts in networking of different actors in order to activate the space and solve the problems on the site.

Valuable industrial buildings should get the status of cultural monument immediately after the production has stopped, in order to prevent their destruction. Establishing a new institution can play a significant role when existing institutions are not efficient and are characterised by constraints. Their independence from the formal institutions enables the implementation of projects outside of traditional models and reduces the impact of existing problems on the process. The establishment of organisations that deal with networking of actors on the site could be significant in creating discussion and constructive criticism.

\section{Innovations and contribution to changing the formal institutional frame- work. The examples from Serbia show innovations coming from the creative and civil sector, and point to the important role they play in activating unused build- ings. Current users of the place are important in the protection and activation of the space and their stay on the site should be supported through mechanisms such as: lower rents for non-profit space users, free counseling, training, technical support, etc. When existing institutional capacities for the protection are insufficient, the city could establish new institutions that would deal with this topic exclusively and have the role of coordinating actors. In cases where formal institutions do not recognize the value of industrial heritage, the initiatives of various informal groups play an important role in highlighting its importance.}

Although significant changes in the official policy in Serbia have not yet happened, small changes show the impact of the bottom-up initiatives and how the innovation is gradually introduced. An example of this is placing Kineska četvrt under preliminary protection after the initiative of non-institutional actors. Also, thanks to the numerous initiatives that took place in this quarter, the space began to be recognized in official documents and public policy. In addition, interviews show that experts in institutions increasingly recognize the potentials of abandoned industrial sites. 
Fig. 10

Summary of the recommendations for actors and public policy

\begin{tabular}{|c|c|}
\hline RECOMMENDATIONS FOR ACTORS & RECOMMENDATIONS FOR PUBLIC POLICY \\
\hline $\begin{array}{l}\text { - Forming the associations and partnerships for } \\
\text { the protection and reuse of buildings } \\
\text { - Raising awareness about the importance of } \\
\text { preserving and activating the heritage } \\
\text { - Activating unused places through temporary } \\
\text { uses } \\
\text { - Connecting with similar initiatives and networks } \\
\text { - Critically observing the current projects and } \\
\text { plans for the site } \\
\text { - Owners should cooperate with new users } \\
\text { and give the unused space for temporary use } \\
\text { or rent under favorable terms, as they could } \\
\text { benefit from this too }\end{array}$ & $\begin{array}{l}\text { - Enabling the cooperation between different } \\
\text { levels and institutions as well as between the } \\
\text { private, public and civil sector } \\
\text { - Establishing effective advisory and supervisory } \\
\text { bodies } \\
\text { - Enabling temporary use and flexibility } \\
\text { - Ensuring the transparency of the process and } \\
\text { the participation of non-institucional actors } \\
\text { - Supporting the initiatives which already exist } \\
\text { on the site } \\
\text { - Introducing measures for protection of vulnera- } \\
\text { ble groups during the urban regeneration } \\
\text { - Establishing instruments and incentives for the } \\
\text { owners } \\
\text { - Incorporating greater restrictions for greenfield } \\
\text { development and supporting the development } \\
\text { on brownfields }\end{array}$ \\
\hline
\end{tabular}

Source: author

\section{Conclusion}

The research showed that non-institutional actors provide innovations which can contribute to changes in the institutional framework and a more efficient treatment of derelict industrial heritage areas, and resulted with the identification of recommendations for overcoming the existing limitations. As the analysed examples show, non-institutional actors have improved, through their activities, the quality of the previously declining industrial areas through informal cooperation, gradual activation and temporary use. The contribution of the research is reflected in the comparison of the process of activating former industrial areas in four EU countries and Serbia. The results point to the importance of bottom-up approaches for the activation and, as such, could represent a small step towards supporting them in the official policy, reducing conflicts among the actors and contributing to the process of activating other abandoned industrial sites. 


\section{References}

1. Backović, V. (2015). Džentrifikacija kao socio-prostorni fenomen sauremenog grada: sociološka analiza koncepata (Gentrification as socio-spatial phenomenon of contemporary city: sociological analysis of the concept). PhD Thesis. Belgrade: Faculty of Philosophy, University of Belgrade.

2. Cizler, J. (2016). Aktivacija napuštenih industrijskih objekata u gradovima: Institucionalna ograničenja u Srbiji (Activation of former industrial areas in cities: Institutional limitations in Serbia). PhD Thesis. Belgrade: Faculty of Architecture, University of Belgrade.

3. Cizler, J. (2012). Urban regeneration effects on industrial heritage and local community - Case study: Leeds, UK. Sociologija i prostor, 50 (2): 223-236.

4. Dević, D.; Komnenić, B. i Mikić, H. (2015). Novi kreativni prostori Vojvodine. Novi Sad: Zavod za kulturu Vojvodine.

5. Ćopić, V. and Dragičević-Šešic M. (2014). challenges of public-civil society relations in cultural policy of Cambodia, 8th International Conference in Cultural Policy research, September 11, Hildesheim.

6. Employee of the JP Poslovni prostor (2015). [Personal interview], December 9.

7. Fece, I. (2015). [Personal interview], December 3.

8. Gligorijević, Z. (2015). [Personal interview], October 28.

9. Golubović, D. i Anđelković, B. (2008). Institucionalni mehanizam saradnje Vlade i civilnog drustva: uporedna iskustva i preporuke za Srbiju (nacrt). [online].

10. Harvey, D. (2013). Rebel Cities: From the Right to the City to the Urban Revolution. London: Verso.

11. Harvey, D. (2009). Social Justice and the City. Athens, Georgia: The University of Georgia Press.

12. Hirt, S. and Stanilov, K. (2009). Twenty Years of Transition: The Evolution of Urban Planning in Eastern Europe and the Former Soviet Union, 1989-2009. Nairobi: UN-HABITAT.

13. Ignjatović, M. (2015). [Personal interview], November 11.

14. Jocić, A. (2015). [Personal interview], November 4.

15. JP Urbanizam (2010). Studija oblikovanja gradskih celina i arbitektonskog oblikovanja objekata u Novom Sadu. [online].

16. Korać, I. (2015). [Personal interview], November 11.

17. Korać, I. i Marković, P. (2009). Inicijativa za izradu projekta i nacrt strateškog plana za revitalizaciju stare fabrike 'Petar Drapšin' u Novom Sadu. Novi Sad.

18. Kulenović, R. (2015). [Personal interview], October 21.

19. Kulenović, R. (2010). Industrijsko nasleđe Beograda. Beograd: Muzej Nauke i tehnike.

20. Kuzmanov, D. (2015). [Personal interview], October 27.

21. Kiš, V. (2015). [Personal interview], October 27.

22. Lazarević-Bajec, N. i Maruna, M. (2009). Strateški urbani dizajn i kulturna raznolikost. Beograd: Arhitektonski fakultet.

23. Lefebvre, H. (1996). Writings on Cities. Oxford: Basil Blackwell.

24. Lowndes, V. (2009). 'New Institutionalism and Urban Politics', in: Davies, J. and Imbroscio, D. (Eds.). Theories of Urban Politics. London: Sage Publications Ltd. 
25. Maksimov, K. (2015). [Personal interview], December 3.

26. Mihajlov, S. (2015). [Personal interview], October 30.

27. Milenković, N. (2015). [Personal interview], November, 20.

28. Nedović-Budić, Z., Zeković, S. and Vujošević, M. (2012). Land Privatization and Management in Serbia - Policy in Limbo. Journal of architectural and planning research, 29 (29): 306-317.

29. Former employee of the City Administration (2015). [Personal interview], 3. December.

30. Oswalt, P.; Overmeyer, K. and Misselwitz, P. (2013). Urban Catalyst: The Power of Temporary Use. DOM Publishers.

31. Pavlović, V. (2006). 'O deficitu institucionalnih kapaciteta u Srbiji', u: Mihajlović, S. (Ur.). Pet godina tranzicije u Srbiji, 2. Beograd: Socijaldemokratski klub, Fondacija Friedrich Ebert, 67-76.

32. Rajić, N. and Vučić, M. (2015). [Personal interview], December 9.

33. Senatsverwaltung für Stadtentwicklung Berlin (2007). Urban Pioneers: Temporary Use and Urban Development in Berlin. Berlin: Jovis.

34. Stojanović, A. i Vukanović, M. (2014). Kulturna politika i zavodi za zaštitu spomenika kulture. Beograd: Zavod za proučavanje kulturnog razvitka.

35. Stojanović, V. i Janjušević, B. (2018). Industrijsko nasleđe u Vojvodini: zaštita, tipologija i moguća revitalizacija danas. Sociology and Space, 56 (1).

36. Tallon, A. (2010). Urban Regeneration in the UK. Oxon: Routledge.

37. Varajić, J. (2015). [Personal interview], November 5.

38. Vujošević, M.; Zeković, S. and Maričić (2010). 'Post-socialist Transition and Empirical Evaluation of the Future Spatial Development of Serbia'. WSEAS Transactions on Environment and Development, vol. 6, no. 9: 666-676.

39. Vukanović, M. (2011). Pogled na kulturu. Zakoni i prakse u Srbiji i pet država članica Evropske unije. Beograd: Zavod za proučavanje kulturnog razvitka.

40. Official Gazette of the City of Belgrade, No. 26/11, Plan detaljne regulacije stambenog naselja 'Višnjičko polje opština Palilula i opština Zvezdara.

41. Official Gazette of the City of Novi Sad, No. 17/17, Plan detaljne regulacije Kineske cetvrti sa Češkim magacinom u Novom Sadu.

This paper is a result of the PhD research conducted between 2009 and 2016 in Serbia, UK, Czech Republic and Austria. I am thankfull to Prof. Dr. Nada Lazarević Bajec and Prof. Dr. Marija Maruna who supervised my PhD thesis at the Faculty of Architecture, University of Belgrade; to Republička fondacija za razvoj naučnog i umetničkog podmlatka, British Scholarship Trust, The International Visegrad Fund, JoinEU Erasmus Mundus Action 2 Program, and to all those who supported the research during this period. 
Jasna Cizler

e-mail: cizlerj@gmail.com

\title{
Aktivacija nekadašnjih industrijskih područja: Kreativni i civilni sektor kao glavni akteri prevladavanja institucionalnih ograničenja u Srbiji
}

\begin{abstract}
Sažetak
Predmet istraživanja ponovna je upotreba nekadašnjih industrijskih područja, kroz inovativne, bottom-up inicijative. Takvi se pristupi već primjenjuju u razvijenim zemljama i postepeno se pojavljuju i u Srbiji, suočavajući se s brojnim ograničenjima. Prva je hipoteza da su institucionalni okvir i postojeća politika aktivacije takvih lokacija u Srbiji neadekvatni. Druga je hipoteza da inicijative civilnog i kreativnog sektora mogu unaprijediti rezultate aktivacije nekadašnjih industrijskih područja. Zadatak je bio ispitati praksu aktivacije u Srbiji, ispitati ograničenja tog procesa i ukazati na mogućnosti za njegovo unapređenje. Metodologija je istraživanja kvalitativna i uključivala je intervjue s relevantnim akterima. Istraživanje se fokusiralo na dvije studije slučaja iz Srbije: 1. kompleks nekadašnje ciglane Trudbenik u Beogradu i 2. nekadašnji industrijski kompleks Kineska četvrt u Novom Sadu. Istraživanje je pokazalo da ograničenja u institucionalnom okviru za aktivaciju nekadašnjih industrijskih objekata u Srbiji mogu biti prevladana kroz veću uključenost neinstitucionalnih inicijativa. Istraživanje je rezultiralo identifikacijom preporuka čiji je cilj uvođenje tih inovacija u proces planiranja urbanog razvoja.
\end{abstract}

Ključne riječi: industrijska baština, urbano planiranje, institucije, neinstitucionalni akteri. 